\author{
ВПЛИВ МЕДІАСЕРЕДОВИЩА НА ФОРМУВАННЯ \\ СОЦІАЛЬНОГО ДОСВІДУ В ДІТЕЙ ДОШКІЛЬНОГО ВІКУ \\ INFLUENCE OF MEDIA ENVIRONMENT ON FORMATION \\ OF SOCIAL EXPERIENCE AT CHILDREN OF PRESCHOOL AGE
}

УДК 373.2.035 + 316.614: [004] DOI https://doi.org/10.32843/2663-60852020-20-2-28

\section{Алєко О.А.,}

канд. пед. наук,

доцент кафредри дошкільної освіти

та соціальної роботи

Донбаського державного педагогічного університету

Кахіані ю.В.

канд. пед. наук,

доцент кафедри дошкільної освіти

та соціальної роботи

Донбаського державного педагогічного університету
Стаття присвячена надзвичайно актуальній проблемі впливу медіасередовища на фоормування соціального досвіду дітей дошкільного віку. Підкреслюється необхідність фрормування в дитини змалечку позитивного соціального досвіду, сталих тенденцій у поведінці, здатностей до самостійного критичного мислення, до засвоєння нових знань, соціальної та моральної зрілості. Висвітлюються різні чинники соціалізації, під вплив яких підпадає дитина з раннього дитинства. Зазначається, що найважливіші для дошкільників чинники мікрорівня: родина, заклад дошкільної освіти, група дітей дошкільного віку, різноманітна спільнота людей, у межах якої діти спілкуються та набувають соціального досвіду, конструюють образ соиіального світу. Наголошується, що сьогодні одними з найвпливовіших чинників набуття та фрормування в дошкільників соціального досвіду стають засоби масової інфрормації. Зосереджується увага на завданнях медіаосвіти, серед яких найважливішими є: сприяння формуванню медіаінформаційної грамотності, медіаімунітету особистості, ресрлексії і критичного мислення як механізму медіаграмотності, здатності до медіатворчості для особистісного самовираження. Подається аналіз позитивних і негативних сторін медіаосвіти дошкільнят. Висвітлюється роль батьків і педагогів у процесі фоормування соціального досвіду під впливом медіасередовища. Зазначається відповідальність дорослих за вплив медіа на дошкільників; наголошується, що безвідповідальне ставлення батьків і педагогів до споживання дітьми медіаінсормаціи стає причиною їх деструктивного впливу на психіку дітей. Також запропоновані поради для поліпшення позитивного впливу медіасередовища на фрормування соціального досвіду дошкільнят

Ключові слова: соціалізація, соціальний досвід, медіасередовище, медіаосвіта, дитина дошкільного віку, батьки, вихователі.
The article is dedicated to the most relevant and current problems of the impact of the media environment on the formation of the social experience of the preschool children. The necessity of formation of the positive social experience, sustainable behavioral trends, capability of critical thinking and obtaining new knowledge, social and moral maturity from early age is underlined. Different socialization factors that influence kids from early childhood are highlighted. It is pointed out that microlevel factors are the most important for the preschool children: family, preschool educational establishment, the group of children of the children, the diversity of people in a group, where children build their relationships and gain social experience. Today one of the most influential factors of formation of the social experience of the preschool children become means of mass communication. Much attention is paid to the tasks of media education, among which the most important are promoting the formation of the media informational literacy, the reflexion and critical thinking as a mechanism of media literacy, capability of media creativity for self-realisation. The analysis of the positive and negative features of the media education of the preschools is given. The role of parents and teachers in the process of formation of the social experience under the influence of media environment is outlined. The responsibility of adults for the impact of media on the pre-schoolers is paid attention to, it is claimed that irresponsibility of parents and teachers becomes the reason of the destructive influence of media information on the psychology of children. Moreover, the advice on improving the positive impact of the media environment on the formation of the social experience of the preschool children is suggested.

Key words: socialization, social experience, media environment, media education, child of preschool age, parents, tutors.
Постановка проблеми в загальному вигляді. 3 огляду на зміни, що відбуваються в сучасному українському суспільстві у зв'язку з розгортанням світових інтеграційних процесів, розширенням кола нових життєвих ситуацій, можливостей для прояву людиною соціальної активності, надзвичайно актуальною постає проблема фрормування соціального досвіду в дітей дошкільного віку.

Закладена в сучасних державних документах (закони України «Про освіту», «Про дошкільну освіту», Національна стратегія розвитку освіти в Україні на 2012-2021 рр., Концепція дошкільного виховання в Україні, Базовий компонент дошкільної освіти (2012р.), Національна програма виховання дітей і учнівської молоді в Україні) методологія освіти надає пріоритетності соціально розвиненій особистості, морально стійкій, соціально адаптованій, що здатна до саморозвитку та безперервного самовдосконалення, може знайти своє місце в житті, відновити духовну культуру суспільства. Зазначене потребує фрормування в дитини змалечку позитивного соціального досвіду, сталих тенденцій у поведінці, розвитку самостійного критичного мислення, здатності до засвоєння нових знань, соціальної та моральної зрілості. 
Особистість дитини 3 раннього дитинства підпадає під вплив різних чинників соціалізації. А. Мудрик умовно поділяє їх на такі групи: мегафрактори (космос, планета, світове співтовариство); макрофрактори (етнос, країна, держава); мікрофактори (родина, заклади навчання та виховання, осередок ровесників) [3]. Найважливіші для дошкільників чинники мікрорівня: родина, заклад дошкільної освіти, група дітей дошкільного віку, різноманітні спільноти, у межах якої діти спілкуються 3 різними категоріями людей, набувають соціального досвіду, конструюють образ соціального світу. Натомість сьогодні одним із найвпливовіших чинників набуття та фрормування в дошкільників соціального досвіду, на нашу думку, стають засоби масової інформації. Є об'єктивні підстави розглядати медіарозвивальне середовище як простір життєдіяльності сучасної дитини, де засоби масової інфрормації стають важливим чинником її соціалізації, і як результат фрормування соціального досвіду дітей.

Аналіз останніх досліджень і публікацій. Нині увага вчених зосереджена на осмисленні, правильному фрормулюванні і розв'язанні педагогічних проблем, що безпосередньо стосуються соціалізації, соціального становлення дітей і молоді. Ці питання порушено у працях І. Беха, О. Безпалько, І. Звєрєвої, І. Єрмакова, В. Мадзігона, А. Капської, Л. Коваль, Н. Лавриченко, Г. Лактіонової, В. Москаленко, Н. Ничкало, В. Оржеховської, С. Савченко, С. Харченка, С. Хлєбік, В. Циби й інших.

Науковці Л. Артемова, А. Богуш, Л. Варяниця, Н. Гавриш, Н. Кирста, О. Кононко, С. Курінна, В. Кузь, Н. Лисенко, Т. Поніманська, І. Яблонська-Рогальська й ін. визначають соціалізацію як набуття дошкільниками соціального досвіду, що здійснюється через діяльність, спрямовану на орієнтування в ситуації, пристосування до навколишнього середовища. Соціальний досвід дитини, на думку вчених, є основою соціалізації, набуваючи його, вона здійснює саморозвиток і самореалізацію, стає соціально компетентною. У нашому дослідженні первинний соціальний досвід ми визначили як слід, що на початковому етапі онтогенезу залишає у свідомості, душі та поведінці дитини практика проживання різних соціальних ситуацій; як сукупність соціальних уявлень, знань, переживань, способів діяльності особистості, що у процесі активної взаємодії з довкіллям, іншими людьми стає особистісним надбанням людини, збагачуючи її внутрішній світ.

Сучасні дошкільники, як у стихійному, так і в педагогічно контрольованому процесі, набувають різноманітного соціального досвіду, що забезпечує розвиток особистості протягом усього життя. Цей досвід дозволяє людині виявитися як справжньому суб'єктові життєдіяльності. Успіш- ність і результативність процесу фрормування в дітей соціального досвіду залежать від багатьох показників: ступеня участі педагогічних працівників і батьків у процесі його фрормування; ступеня засвоєння соціальних знань, умінь, навичок; рівня розвитку самосвідомості; ступеня прояву в дитини активної позиції стосовно свого найближчого оточення. Одним із найвпливовіших чинників набуття дошкільниками соціального досвіду на сучасному етапі, на наше переконання, стає медіасередовище як розвивальний простір життєдіяльності сучасної дитини.

Мета статті - охарактеризувати вплив медіасередовища на процес формування соціального досвіду в дітей дошкільного віку.

Виклад основного матеріалу. 21 квітня 2016 р. Президія Національної академії педагогічних наук України схвалила нову редакцію «Концепції впровадження медіаосвіти в Україні». Головними завданнями медіаосвіти є сприяння форомуванню:

- медіаінфрормаційної грамотності як комплексу вмінь, знань, розуміння і відносин, які дають споживачам можливість: ефективно і безпечно користуватися медіа, усвідомлено обирати, розуміти характер контенту і послуг, а також можливість захистити себе і свою сім'ю від шкідливого або вразливого інформаційного матеріалу;

- медіаімунітету особистості, який робить її здатною протистояти агресивному медіасередовищу і деструктивним медіаінфрормаційним впливам;

- рефлексії та критичного мислення як механізму медіаграмотності;

- здатності до медіатворчості для самовираження особистості та реалізації їі життєвих завдань, різних аспектів медіакультури (візуальної, музичної, опосередкованих масмедіа, сучасних напрямів медіаарту) [1].

Концепція спрямована на підготовку і проведення повномасштабної поетапної роботи з упровадження медіаосвіти в Україні. Форми медіаосвіти визначено, згідно з Концепцією, за віковими рівнями здобуття освіти.

Медіаосвіта дошкільна є принципово інтегрованою і спрямована на збалансований естетичний та інтелектуальний розвиток особистості дитини (включаючи різні фрорми інтелекту, зокрема, емоційний, соціальний і практичний інтелект), забезпечує її захист від агресивного медіасередовища (від інфрормаційного «сміття», невідповідних віковим можливостям психіки дитини інфрормаційних впливів, зокрема продукції, що містить елементи насильства, жахів, еротики), уміння орієнтуватись, обирати і використовувати адаптовану відповідно до вікових норм медіапродукцію [1]. Але, на жаль, принципи, закладені в Концепції, дещо розбігаються $з$ реальною дійсністю. Медіаінфрормаційна безпека особистості залежить від ужиття 
запобіжних заходів у медіаінформаційному полі з боку держави, а також від здатності кожної окремої особистості чинити опір деструктивним медіаінформаційним впливам - психологічним технологіям впливу.

Роль засобів масової інформації (далі - 3MI) у фрормуванні особистості розглядали багато сучасних науковців, серед них: Н. Горячев, С. Дем'янчук, В. Єгоров, Н. Іванова, І. Кіндрат, Ю. Лошкарьов, А. Мудрик, К. Парсяк, О. Петрунько, С. Семчук, М. Тиморшин та ін. Проблемам медіаосвіти й аудіовізуальної грамотності молодого покоління присвятили свої дослідження Ж. Берже, А. Моль, Л. Поршер, М. Тарді, С. Френе.

Науковцями (В. Абраменкова, Г. Апостолова, Н. Повякель) доведено, що сучасний дошкільник більшість часу перебуває під впливом 3МІ, що неухильно позначається на його індивідуальному розвитку і соціальному становленні. Дослідниця О. Петрунько вважає, що сьогодні традиційні інститути (сім'я, заклад дошкільної освіти) істотно послабили свій вплив на соціалізацію дитини, а їхні функції поступово перейшли до ЗМІ. У своєму дослідженні ми не настільки категоричні і в жодному разі не заперечуємо провідну роль родини і дошкільного закладу в соціалізації особистості. Але ми не можемо не погодитись із думкою дослідниці, яка стверджує, що поступово психосоціальна система «соціум - особистість» змінюється за своєю структурою, змістом і набуває вигляду «соціум - масмедіа - особистість» [5].

Науковець С. Семчук зауважує, що соціальний розвиток дитини-дошкільника в контексті впливу ЗМІ здійснюється за двома взаємозалежними лініями. 3 одного боку, суспільство завдяки поширенню ЗМІ надає молодій особистості інформацію у вигляді певних стереотипів поведінки. Через інформацію, що надається у $3 \mathrm{MI}$, дитина поступово оволодіває суспільним досвідом (здобуває знання, формує вміння, особистісні потреби, здібності, почуття), відповідно до власного досвіду і розуміння розширює та систематизуєїх. 3 іншого боку, дитина не лише усвідомлює, а й реалізує себе як суб'єкт широкого кола суспільних взаємин [8, с. 7].

Ми не можемо заперечувати той фракт, що медіа сьогодні - одна з найважливіших сорер у житті людей всієї планети. На межі XX-XXI ст. екранні медіа (а саме телебачення й Інтернет) безповоротно потіснили друковані ЗМІ, дістали левову частку світового інформаційного простору, перетворивши його на медіапростір [5, с. 226]. Більшість читачів перетворилися на глядачів, яким незалежно від віку доступна будь-яка інорормація в необмеженій кількості. Навіть діти дошкільного віку стають свідками небезпечних і травматичних подій на екрані (сцени жорстокості та насильства), а також споживають інорормацію, яка деструктивно впливає на їхню психіку і поведінку.
Стрімкі зміни в інфрормаційному освітньому просторі не залишили осторонь від цих процесів дитину-дошкільника. Порівнюючи темпи життя й обсяги знань дитини нашого століття і дитини, яка жила 200-300 років тому, дослідниця М. Саакянц доводить, що результати цього порівняння не завжди будуть на користь дітей третього тисячоліття. Серед негативних чинників, які сьогодні небажано впливають на здоров'я та психіку дитини, науковець виокремлює такі: екологічні чинники (забруднення життєвого середовища, хімічні й мутагенні продукти харчування); надзвичайний обсяг інформації (телебачення, радіо, Інтернет, література, спілкування); зростання ролі техніки в житті людини (іноді батьки дитини через життєві ситуації значну частину часу проводять біля комп'ютера, різних механізмів, а відпочинок біля телевізора); недостатній фрізичний ритм життя (іноді рух дитини обмежується лише шляхом до закладу дошкільної освіти чи школи); патологічний вплив телебачення, преси, Інтернету (нав'язлива реклама, фрривольні програми, втома очей). Надзвичайний обсяг інфрормації, яка сьогодні їі оточує, вимагає підготовки дитини до життєдіяльності й освіти в такому насиченому середовищі вже на етапах підготовки до школи [7, с. 192].

Серед аудіовізуальних медіа особливу роль відіграє телебачення. Проведене нами опитування батьків дітей дошкільного віку для вивчення ступеня «споживання» дітьми різних видів 3МІ показало, що перші контакти з телебаченням діти мають уже на другому році життя. У віковій групі 2-3-річних дітей уже 60\% дивляться телепередачі регулярно. У дошкільному віці дитина просиджує щодня перед телевізором у середньому чотири години, переглядаючи програми, адресовані здебільшого дорослій аудиторії. Ці дані збігаються з результатами соціологічних опитувань (В. Абраменкова, Н. Авдєєва, А. Богатирьов), які доводять, що телебачення посіло одне із провідних місць за силою виховного впливу після сім'ї та закладу дошкільної освіти. За результатами опитування батьків, 50\% дітей дивляться телепередачі без будь-якого вибору й обмежень.

Безперечно, добрий, якісний мульторільм-конче потрібний матеріал для розвитку ігрових сюжетів, для малювання, ліплення та й загалом формування позитивного соціального досвіду дітей; він формує в дитячій свідомості модель навколишнього світу, образи мами і тата, друга і ворога, усього того, на що дитина орієнтуватиметься все життя як на духовний компас.

Діти завжди асоціюють себе з головним персонажем твору, чи то книжки, чи то мультику. Зазвичай дівчаток ваблять жіночі образи, а хлопчиків - чоловічі, що цілком закономірно. На жаль, не всі сучасні мульторільми відповідають усім необхідним вимогам. Більшості з них притаманні 
ознаки, які роблять їх небажаними для перегляду дошкільнятами.

Дослідники з'ясували, що діти дивляться не тільки мультфільми, дитячі серіали, передачі та художні фрільми. Вони є найбільш активними реципієнтами рекламного повідомлення (у середньому кожний другий дошкільник дивиться рекламу та телепрограми, що орієнтовані на дорослу аудиторію) [4, с. 84].

Телебачення привертає увагу дітей терапевтичною, рекреативною, розважальною, естетичною, пізнавальною, інформаційною, комунікативною функціями. Водночас для дитини воно може стати як інструментом для подальшого розвитку, формування світогляду, самовиховання, набуття нових знань та поглядів, так і джерелом агресії, насильства, антиморальності, конфрліктності. Це положення підтверджується низкою досліджень, проведених у сучасній експериментальній психології (О. Агузарова, А. Асмолов, Ю. Василькіна, Е. Сигман, Д. Халфорд), які розкривають негативний вплив телебачення на психофізіологію дитини.

Зображення на екрані телевізора не сприяє формуванню просторового та кольорового зору, форма та стиль зображення людей і речей у мульторільмах (грубі, квадратні або інші неприродні риси обличчя, тіла тощо) спотворюють сприймання й уявлення дітьми цих персонажів в об'єктивній реальності. Особливо це шкідливо в дошкільному віці, коли активно фрормуються внутрішні образи та внутрішній план дій. Відбувається це зазвичай за допомогою дорослого, який розповідає, читає дитині казки, під час прослуховування яких дитина намагається уявити події, запам'ятати та пережити їх. Коли дитина сприймає вже сконструйовану на екрані реальність, споживає готові образи, її внутрішні образи пасивні та позбавлені індивідуальності, у неї відсутня можливість вияву франтазії і творчості.

Разом із сучасними дослідниками ми переконані, що дитина-дошкільник не встигає переробляти, аналізувати, узагальнювати й оцінювати інсрормацію, унаслідок чого виховується пасивний споглядач, а не критичний споживач. Дошкільники починають мислити готовими асоціаціями, ставлять поверхові запитання, відповіді також дають поверхові.

Беззаперечним $€$ той фракт, що телебачення впливає на вольову сореру й поведінку дітей. Проведене нами спостереження за старшими дошкільниками у процесі сюжетно-рольових ігор, зокрема «Магазин», «Доньки-матері», «Лікарня», «Перукарня», свідчить про те, що досить часто діти повторюють певні фррази з реклами, телепередач (копіюючи висловлювання улюблених телегероїв). Отже, після емоційного сприйняття медіапродукції дитиною настає етап неусвідомленого наслідування нею запропонованого телебаченням стилю поведінки. Телебачення передбачає готові взірці поведінки замість того, щоб фрормувати вміння розв'язувати проблеми; отже, незабаром будемо мати покоління наслідувачів, а не митців.

Другим за частотою застосування та силою впливу на свідомість дитини є комп'ютер. Сучасна дитина зростає в середовищі, де комп'ютер - така ж звичайна й буденна річ, як електричне освітлення, автомобілі, телевізори або мобільні телефони. Надмірне захоплення телепередачами, фрільмами та комп'ютерними іграми сприяє й розвиткові дитячої гіподинамії, яка набуває все більш загрозливих масштабів. Після тривалого, відносно нерухомого сидіння біля телевізора в дитини може розвинутися неприродне збудження як компенсація попереднього стану гіподинамії. Вона деякий час не може зосередити свою увагу, не знає, «куди себе подіти».

Водночас застосування сучасних інформаційно-комунікаційних технологій посилює навантаження на організм дитини, викликає стійку залежність. Ми погоджуємось із дослідженнями І. Кіндрат, яка довела, що тривала робота за комп'ютером негативно позначається на багатьох функціях дитячого організму: на нервовій діяльності, ендокринній, імунній та репродуктивній системах, органах зору й кістково-м'язовому апараті, тому недотримання санітарних норм використання комп'ютера може стати причиною: загального нездужання (сонливість або, навпаки, безсоння, швидка втомлюваність, головний біль, біль у ногах, зап'ястках, шиї, спині й ін.); захворювання органів зору (швидка стомлюваність, свербіння, сльозливість, порушення візуального сприйняття на дальній та близькій відстанях); погіршення зосередженості та працездатності; захворювання опорно-рухового апарату (розвиток патологічних викривлень хребта, остеохондроз, зміщення або десрормація міжхребцевих дисків та ін.); захворювання рук; гіподинамії [2, с. 97].

Разом із науковцем О. Петрунько ми впевнені, що психічне здоров'я дитини страждає внаслідок інтернет-залежності, зокрема від захоплення іграми за технологією віртуальної реальності. У дітей спостерігається зниження критичності через велику кількість недостовірної інорормації; втеча від реального життя у віртуальний світ, втрата відчуття Я - реального; відбувається затримка розвитку всіх психічних процесів [6].

Дуже часто дитина залишається самотньою в цьому людино-машинному світі. Майже цілковита відсутність спілкування з однолітками, недостатня увага з боку батьків через зайнятість. Усі ці причини дуже часто підштовхують дитину до занурення в комп'ютерне задзеркалля, з якого вона і накопичує соціальний досвід, іноді дуже спотворений. Комп'ютерні засоби мають бути для дитини інструментом отримання знань, а не засобом 
створити віртуальну реальність, за якою можна сховатись від реалій життя.

М. Саакянц вбачає два можливі напрями розвитку подій для дитини-дошкільника в сучасному інфрормаційному суспільстві. Один із них полягає в тому, що батьки, які досконало володіють комп'ютерними технологіями, знають як позитивні, так і негативні впливи, які персональний комп'ютер здійснює на організм, та уникають негативу, поступово вводять дитину у світ сучасних інформаційнокомунікаційних технологій. Позитивний розвиток таких подій передбачає: пояснення дитині тривалості роботи-гри за комп'ютером і того, як вона може зашкодити здоров'ю; дотримання встановленого часу роботи на комп'ютері; дуже ретельний підбір техніки за параметрами мінімальної фрізичної шкоди дитячому організму; особливий контроль за тими програмами, з якими буде працювати дитина. Одна 3 найскладніших проблем полягає у фрільтрації батьками тих програмних продуктів, які пропонує сучасний ринок для дітей дошкільного віку [4, с. 193].

Другий напрям розвитку подій має негативні тенденції. Коли батьки, придбавши сучасну комп'ютерну техніку, не здійснюють контролю за комп'ютеризованою ігровою діяльністю дитини. Не кожна ігрова програма і далеко не кожний дитячий мультиплікаційний фрільм принесуть дитині користь. Науковці всього світу б'ють на сполох через негативний вплив на дитячу психіку низки мульторільмів, які несуть бездушність, агресію, жорстокість.

Ми погоджуємось із думкою О. Петрунько, яка зауважує, що відповідальність за вплив медіа на дошкільника цілковито покладається на дорослих, які «мають достеменно знати, що саме дивляться їхні діти, бути готовими обговорювати з ними побачене, висловлювати свої думки і зауваження щодо цього, відповідати на запитання дітей, а також ставити свої запитання дітям» [3, с. 110]. Безвідповідальне ставлення батьків і педагогів до споживання дітьми інформації, яку пропонують медіа масового призначення, часто стає причиною їхнього деструктивного впливу на психіку дітей, активації різноманітних страхів у дітей.

Отже, щоб ефект впливу медіасередовища був позитивним, батьки мають вчитися слухати й чути свою дитину, бути толерантними і терплячими, розуміти її, вчасно помічати в ній небажані зміни. Любов до дитини має виражатися не лише в подарунках - іграшках, солодощах, а ще й у частішому спілкуванні із сином чи донькою. Важливо відбирати лише якісні, добрі, пізнавальні й розвивальні мультфільми, телепередачі, відеоролики. Обов'язково обговорювати з малечею переглянутий сюжет, персонажів, аналізувати образи, привертати увагу малюка до того, що лишилося непоміченим, спонукати творчо осмислювати побачене.

Батькам і педагогам доцільно знайомити дитину 3 добрими дитячими журналами, спрямованими на особистісний розвиток малюка, його моральне становлення, фрормування позитивного соціального досвіду. У процесі читання журналу, пошуку відповідей на його запитання, варіантів розв'язання задач і способів виконання завдань і дорослий, і дитина разом розмірковують, обговорюють, висловлюють думки і почуття, разом творять красу, що дає їм спільну радість і краще розуміння одне одного, а дорослому - дієві важелі позитивного впливу на малюка.

Існує безліч цікавих і корисних для дитини спільних справ, окрім тих, що пов'язані з інтернетом або телебаченням. Наприклад, можна разом займатись хатніми справами, доглядом за домашніми улюбленцями, спортом; разом можна майструвати, ліпити, малювати, франтазувати, мріяти; читати улюблені книжки, розглядати ілюстрації, сімейні фротографрії; відвідувати музеї, театри, виставки або просто гуляти.

Усе вищезазначене вимагає від батьків певних зусиль, праці, часу; однак, доклавши їх, можна захистити дитину від інформаційних потоків, які не дають доброї поживи ні розуму, ні серцю, руйнують духовне здоров'я.

Німецький дослідник у галузі медіапсихології Р. Пацлафр уважає, що рішення дорослих «не допускати до телевізора» дітей дошкільного віку $€$ цілком слушним і обґрунтованим. Як свідчить педагогічно-виховна практика, дошкільники цілком задовольняються тією інфрормацією про влаштування світу і соціальне життя, яку їм надають батьки, вихователі закладів дошкільної освіти й інші близькі дорослі, на яких покладено відповідальність за їхній психоемоційний добробут [2].

Маємо бути реалістами: зовсім уникнути медіасередовища сьогодні неможливо, тому необхідно педагогам і батькам об'єднати зусилля для виховання в дітей культури користування інфрормацією.

Висновки. Дорослі, які оточують дитинудошкільника, мають чітко усвідомлювати свою відповідальність за емоційне здоров'я, процеси соціалізації і формування соціального досвіду дітей, які зростають у медіасуспільстві; вони повинні ставити собі завдання з розвитку власної медіаграмотності та медіакультури, щоби почуватися спроможними здійснювати належний психологічний супровід власних дітей у сучасному, перенасиченому насильством і агресією, ненадійному медіасередовищі.

Перспективи подальших досліджень вбачаємо в удосконаленні та розробці новітніх фрорм і методів взаємодії педагогів закладів дошкільної освіти з батьками з означеної проблеми. 
БІБЛІОГРАФІЧНИЙ СПИСОК:

1. Концепція впровадження медіаосвіти в Україні. Редакція 2016 р. URL: http://osvita.mediasapiens. ua/mediaprosvita/mediaosvita/kontseptsiya_ vprovadzhennya_mediaosviti_v_ukraini_nova_ redaktsiya/.

2. Кіндрат І. Вплив сучасного медіа-простору на формування світоглядних уявлень дитини дошкільного віку. Вісник Луганського національного універcumeme імені Тараса Шевченка. 2013. № 13 (272). 4. III. C. $97-110$.

3. Мудрик А. Социализация человека как проблема. Социальная педагогика. 2005. № 4. C. 47-57.

4. Парсяк К. Особливості дитячих телевізійних телепередач на українському телебаченні. Збірник матеріалів I Міжвузівської студентської науково- практичної конфреренції. Донецьк : вид-во ДІСО, 2009. Вип. 1. 100 c.

5. Петрунько О. Діти і медіа: соціалізація в агресивному медіасередовищ і: монографрія. 2-ге вид. Ніжин : ТОВ «Вид. «Аспект-Поліграфр», 2011. 480 с.

6. Петрунько О. Медіасоціалізація, або соціалізація 3 медіа замість соціалізації 3 дорослими. Психологічні перспективи. Спец. випуск. Луцьк, 2010. C. 103-113.

7. Саакянц М. Зміна парадигми теорії ігрової діяльності в сучасному освітньому просторі. Ч. 2 Конференції «Дитинство в сучасному світі: перші 7 років і все життя». Запоріжжя, 2010. 344 с.

8. Семчук С. Особливості впливу засобів масової інформації на соціалізацію дітей дошкільного віку : автореф. дис. ... канд. пед. наук: 13.00.08. Одеса, 2010. 20 с. 